\title{
Performans Sapi Aceh yang diberi Pakan Eceng Gondok (Eichhorniacrassipes) Fermentasi dengan Probiotik aspergillus niger sebagai Subtitusi Rumput Gajah dan Rumput Lapangan
}

\author{
(Performance of Aceh Bullock that Given Feed Water Hyacinth \\ (Eichhornia Crassipes)with Fermentation Probiotic Aspergillus Niger as a \\ Substitute Elephant Grass and Grass Field) \\ Mahyuddin $^{1}$, Asril $^{1}$, Mudatsir ${ }^{1}$ \\ ${ }^{1}$ Program Studi Peternakan, Fakultas Pertanian, Universitas Syiah Kuala
}

\begin{abstract}
Abstrak: Penelitian tentang Performans Sapi Aceh yang diberikan Pakan EcengGondok (Eichhornia Crassipes) Fermentasi dengan Probiotik Aspergillusniger sebagai Subtitusi Rumput Gajah dan Rumput Lapangan telah dilakukan di Laboratorium Lapangan Peternakan Prodi Peternakan Fakultas Pertanian Universitas Syiah Kuala Darussalam Banda Aceh. Penelitian ini berlangsung selama 112 haridari tanggal 24 Januari 2016 - 08 Mei 2016.Tujuan penelitian ini adalah untuk mengetahui performans sapi Aceh jantan yang diberikanpakan eceng gondok yang difermentasi dengan Aspergillus nigersebagai subtitusi rumput gajah dan rumput lapangan. Materi penelitian ini adalah 4 ekor sapi Aceh jantan dan menggunakan Rancangan Bujur Sangkar Latin (RBSL), yang terdiri dari 4 perlakuan dan 4 ulangan, Masing-masing perlakuan adalah pelakuan $\mathrm{A}(0 \%$ eceng gondok fermentasi) perlakuan B (10\% eceng gondok fermentasi), perlakuan C ( $20 \%$ eceng gondok fermentasi),dan pelakuan D (30\% eceng gondok fermentasi). Data penelitian yang diperoleh dianalisis menggunakan ANOVA (Analysis of Variance). Parameter yang diamati adalah:Pertambahan berat badan, Konsumsi pakan, dan Konversi pakan. Hasil penelitian menunjukkan tidak terjadi perbedaan yang nyata $(\mathrm{P}>0.05)$ terhadap konsumsi pakan dan konversi pakan. Namun terjadi perbedaan yang nyata $(\mathrm{p}<0,05)$ pada parameter pertambahan berat badan.
\end{abstract}

Kata kunci: sapi aceh jantan, eceng gondok fermentasi, pakan hijauan, pertumbuhan.

\begin{abstract}
Experiment on Performance of Aceh Bulls was given feed water hyacinth (Eichhornia crassipes) Fermentation with Probiotics Aspergillus niger as substitution of Elephant Grass and Grass Field has done in Field Laboratory Animal Husbandry Faculty of Agriculture, the University of Syiah Kuala in Banda Aceh Darussalam. The study lasted 112 days from the date of January 24, 2016 - May 8, 2016. The purpose of this study was to determine the performance of Aceh Bulls are given feed hyacinth fermented with Aspergillus niger as a substitute for grass and field turf. The material of this study was 4 Aceh Bulls and using design Latin square (RBSL), which consists of 4 treatments and 4 repitulations, each treatment is the carrying out of A ( $0 \%$ water hyacinth fermentation) treatment B (10\% water hyacinth fermentation ), treatment C (20\% water hyacinth fermentation), and treatment $\mathrm{D}$ ( $30 \%$ water hyacinth fermentation). The research data were analyzed using ANOVA (Analysis of Variance). Parameters measured were: weight gain, feed intake, feed conversion. The results showed no differences were significant against $(\mathrm{P}>0.05)$, feed intake and feed conversion. But there is a significant difference $(\mathrm{p}<0.05)$ on the parameters of weight gain.
\end{abstract}

Keywords: aceh bulls, water hyacinth fermentation, feed forage, growth.

\section{PENDAHULUAN}

Salah satu faktor utama dalam usaha peternakan salah adalah pakan, karena pakan mengandung nutrisi untuk pertumbuhan dan produktivitas ternak.Ternak ruminansia sangat tergantung pada pakan hijauan.Permasalahan utama di Indonesia dalam pengembangan produksi ternak ruminansia adalah sulitnya memenuhi ketersediaan pakan baik kualitas, kuantitas maupun kontinuitas. Produktivitas hijauan sangat berfluktuasi, melimpah pada musim hujan, namun 
terjadi kelangkaan saat kemarau terutama pada daerah padat ternak namun lahan kurang. Pakan hijauan untuk ternak ruminansia dapat berupa hijauan segar yang terdiri dari rumput, legum dan daun-daunan atau dapat berupa limbah pertanian baik yang segar maupun yang kering (Nuschati, 2006).

Usaha untuk mencari bahan pakan murah dan penemuan teknologi tepat guna dalam pemanfaatannya masih terus dilakukan, guna membantu pemecahan masalah penyediaan pakan.Strategi pemberian pakan ternak yang efisien adalah memanfaatkan sumber daya lokal yang melimpah dan bernilai gizi baik bagi ternak.Salah satunya adalah melalui pemanfaatan eceng gondok dengan teknologi fermentasi. Menurut Fitrihidajati (2015) eceng gondok memang sangat potensial untuk pakan ternak, karena kandunganproteinnya yang tinggi $(11,2 \%)$ namun satu kelemahan eceng gondok adalah kecernaannya yang rendah karena banyak mengandung serat kasar $(16,79 \%)$.

Eceng gondok merupakan tumbuhan air, dan merupakan salah satu jenis gulma air yang perkembangannya sangat cepat dan mempunyai daya penyesuaian terhadap lingkungan yang tinggi (Fuskhah, 2000).Aspergillus niger merupakan mikroba jenis kapang yang dapat tumbuh cepat dan tidak membahayakan karena tidak menghasilkan mikotoksin dan mudah dikembangkan (Gras, 2008). Fermentasi dapat menyebabkan perubahan sifat bahan dasar sebagai pemecahan kandungan bahan oleh masa sel mikrobia yang terjadi selama proses fermentasi. Selama proses fermentasi terjadi perubahan-perubahan terhadap komposisi kimia bahan akibat aktivitas dan perkembangbiakan mikroorganisme, seperti kandungan asam amino, lemak, karbohidrat, vitamin dan mineral (Mangisah et al., 2003).

Berdasarkan tingginya kadar protein eceng gondok yang sudah difermentasi maka perlu dilakukan penelitian untuk mengetahui apakah terjadi pengaruh yang baik terhadap pertambahan berat badan sapi Aceh jantan yang diberikan pakan eceng gondok yang difermentasi dengan Aspergillus niger sebagai bahan pakan alternatif.

\section{METODE PENELITIAN}

Penelitian ini dilaksanakan di Laboratorium Lapangan Peternakan Prodi Peternakan Fakultas Pertanian Universitas Syiah Kuala Darussalam Banda Aceh pada tanggal 24 Januari 2016 - 08 Mei 2016.

\section{Sapi Aceh Jantan}

\section{MATERI DAN METODE}

Sampel yang dipakai dalam penelitian ini adalah empat ekor sapi Aceh jantan dengan kisaran umur antara 2 tahun - 2,5 tahun dan berat badan antara 240 $\mathrm{kg}-260 \mathrm{~kg}$.

\section{Metode Penelitian}

Pada penelitian pendahuluan dilakukan survei kebeberapa toko dan swalayan untuk mencari semua susu pasteurisasi komersial yang memiliki izin Departemen Kesehatan. Selain itu sampel susu yang dipakai mempunyai masa kadaluwarsa yang optimum (produksi awal). Selanjutnya dilakukan pengujian kekeruhan dan kualitas susu juga uji keberadaan Staphylococcus aureus.

\section{Prosedur Penelitian}


Sapi - sapi yang dijadikan materi penelitian dipilih terlebih dahulu, pemilihansapi - sapi ini bertujuan untuk mendapatkan keseragaman antar sapi, baik itu jenis kelamin, umur, maupun berat badan sapi, hasil pemilihan di dapatkan umur sapi rata - rata berkisar $2-2,5$ tahun, dengan berat badan sapi $\mathrm{A}=$ $260 \mathrm{~kg}$, sapi B = $248 \mathrm{~kg}$, sapi $\mathrm{C}=246 \mathrm{~kg}$ dan sapi D = $239 \mathrm{~kg}$. Selanjutnya sapi tersebut di adaptasi untuk memudahkan dalam pengumpulan data, guna mengurangi kesalahan dalan analisis data serta menyesuaikan dengan perlakuan penelitian.Adaptasi pemberian pakan dilakukan selama seminggu, selanjutnya sapi ditimbang untuk mendapatkan data awal berat badan sapi, tujuan dilakukan proses adaptasi terlebih dahulu adalah untuk mempersiapkan sapi menerima pakan perlakuan padaparameter yang akan diteliti.

Sapi yang dijadikan materi penelitian adalah bangsa sapi Aceh jantan.Pemberian pakan sapi dilakukan pagi hari pukul $08.00-10.00$ WIB dan sore hari pukul 16.00 - 18.00 WIB dengan pemberian kombinasi bahan pakan antara rumput gajah, rumput lapangan dan eceng gondok fermentasi. Air Minum diberikan adlibitum yaitu pemberian air minum tidak dibatasi sehingga sapi dapat minum air setiap saat diperlukan.

\section{Parameter yang Diamati}

\section{Pertambahan Berat Badan Harian (PBBH)}

Penambahan berat badan harian dihitung dari penimbangan berat badan hari ke 21 dikurangi berat badan hari ke 1 lalu di bagi lama pengamatan (21 hari) untuk di ambil nilai rata - rata pertambahan berat badan harian (satuan $\mathrm{kg}$ ).

\section{Konsumsi Pakan}

Data mengenai konsumsi pakan diperoleh dengan menghitung jumlah pakan yang diberikan dikurangi dengan jumlah pakan yang tersisa (satuan $\mathrm{kg}$ ).

\section{Konversi Pakan}

Perbandingan antara jumlah pakan yang dikonsumsi pada waktu tertentu dengan pertambahan berat badan yang dihasilkan.Untuk mendapatkan hasil konversi pakan konsumsi bahan kering pakan dibagi pertambahan bobot badan.

\section{Analisa Statistik}

Data yang diperoleh dianalisis dengan sidik ragam. Apabila terdapat perbedaan antar perlakuan maka dilanjutkan dengan Uji Jarak Berganda Duncan (Duncan Multiple Range Test) (Steel dan Torrie, 1991).

\section{HASIL DAN PEMBAHASAN}

\section{Pertambahan Berat Badan}

Pertambahan bobot badan harian ternak sapi Aceh diperoleh dari hasil penimbangan bobot badan akhir dikurangi dengan bobot badan awal dibagi selang waktu penimbangan yaitu 21 hari sekali.Rataan pertambahan bobot badan harian $(\mathrm{PBBH})$ sapi Aceh pada umur berbeda dapat dilihat pada Tabel 6.

Tabel 6. Pertambahan Berat Badan Harian Sapi Aceh Jantan (kg/Hari/Ekor) 


\begin{tabular}{|c|c|c|c|c|c|c|}
\hline \multirow{2}{*}{ Periode } & \multicolumn{4}{|c|}{ Pakan Perlakuan } & \multirow{2}{*}{ Total } & \multirow{2}{*}{ Rerata } \\
\hline & $\mathrm{A}$ & $\mathrm{B}$ & $\mathrm{C}$ & $\mathrm{D}$ & & \\
\hline $\mathrm{I}$ & 0,476 & 0,381 & 0,333 & 0,190 & 1,381 & 0,345 \\
\hline II & 0,524 & 0,381 & 0,381 & 0,333 & 1,619 & 0,405 \\
\hline III & 0,476 & 0,381 & 0,286 & 0,381 & 1,524 & 0,381 \\
\hline IV & 0,381 & 0,429 & 0,429 & 0,143 & 1,381 & 0,345 \\
\hline Total & 1,857 & 1,571 & 1,429 & 1,048 & 5,905 & \\
\hline Rerata & $\begin{array}{l}0,464^{\mathrm{a}} \\
\pm 0,030\end{array}$ & $\begin{array}{l}0,393^{\mathrm{a}} \\
\pm 0,012\end{array}$ & $\begin{array}{l}0,357^{\mathrm{a}} \\
\pm 0,031\end{array}$ & $\begin{array}{l}0,262^{b} \\
\pm 0,057\end{array}$ & & \\
\hline
\end{tabular}

Keterangan: Superskrip yang berbeda pada kolom berbeda menunjukkan perbedaan yang nyata $(\mathrm{P}<0,05)$

Berdasarkan rataan pertambahan berat badan sapi Aceh jantan yang diberi pakan berbasis rumput gajah, rumput lapangan dan eceng gondok fermentasi menunjukkan hasil yang berbeda nyata $(\mathrm{P}<0,05)$ antara perlakuan $\mathrm{A}, \mathrm{B}$ dan $\mathrm{C}$ dan D. Tabel 4 diatas memperlihatkan bahwa pertambahan berat badan sapi Aceh tertinggi yaitu pada sapi yang diberikan pakan perlakuan A tanpa pemberian eceng gondok fermentasi dengan pertambahan berat badan harian sebesar $0,46 \pm 0,030 \mathrm{~kg} / \mathrm{hari}$. Sedangkan pertambahan badan harian cenderung rendah pada sapi yang diberikan pakan perlakuan D (eceng gondok fermentasi sebanyak 30\%) yaitu pertambahan berat $0,26 \pm 0,057 \mathrm{~kg} / \mathrm{hari}$.

Pakan perlakuan D berbeda nyata dengan pakan perlakuan A, pakan perlakuan B dan pakan perlakuan C. Saleh et al. (2005) menyatakan peningkatan komposisi ecenggondok dalam ransum sampai level $15 \%$ dapat meningkatkan konsumsi ransum ayam broiler, tetapi pada level $20 \%$ masih memberikan hasil yang positif. Hal ini menunjukkan bahwa pemberian eceng godok fermentasi untuk subtitusi dapat diberikan sampai $20 \%$ karena masih menunjukkan adanya pertambahan berat badan harian tidak begitu jauh dengan perlakuan A (tanpa subtitusi).

Eceng gondok fermentasi pada penelitian ini mempunyai tingkat palatabilitas yang rendah pada pemberian pakan D (30\%) sehingga terjadi penurunan tingkat konsumsi pakan dan terjadi penurunan pertambahan berat badan. Menurut Lubis (1992), kecernaan nutrien ransum selain dipengaruhi oleh kandungan serat kasar, dipengaruhi juga oleh persentase protein dalam ransum dan jumlah protein yangdikonsumsi.

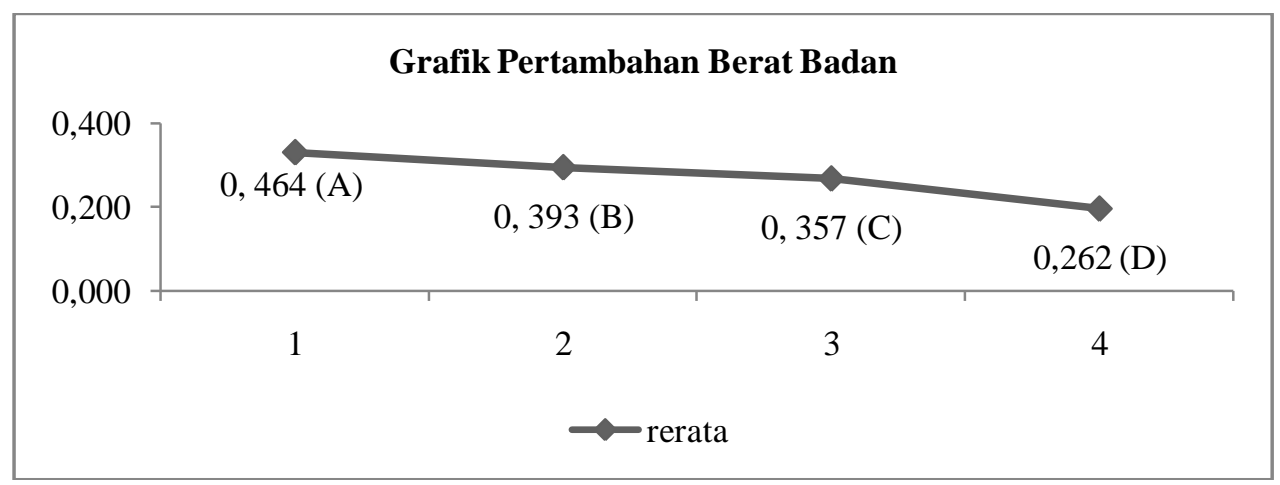

Gambar 1. Grafik Pertambahan Berat Badan 
Grafik pada gambar di atas menunjukkan bahwa rataan pertambahan berat badan harian sapi Aceh jantan maksimum terdapat pada perlakuan A $(0,46 \pm 0,030$ $\mathrm{kg})$, diikuti perlakuan $\mathrm{B}(0,39 \pm 0,012 \mathrm{~kg})$, perlakuan $\mathrm{C}(0,35 \pm 0,031 \mathrm{~kg})$ dan perlakuan D $(0,26 \pm 0,057 \mathrm{~kg})$. Pertumbuhan pada ternak dapat dinilai sebagai peningkatan tinggi, panjang, ukuran lingkar dan bobot badan yang terjadi pada ternak yang sehat serta diberi pakan, minum dan mendapat tempat berteduh yang layak.

Anti nutrisi di dalam ransum dengan campuran eceng gondok fermentasi, pada pakan perlakuanC $(20 \%)$ dan D (30\%) kemungkinan terjadinya akumulasi anti nutrisi yang lebih tinggi, yang terdiri dari asam oksalat, asam sianida dan asam nitrat. Oksalat merupakan salah satu komponen nonpolisakarida dari dinding sel tumbuhan yang dapat mengikat mineral seperti kalsium, magnesium, sodium dan potasium.

Defisiensi kalsium dan potassium dapat menyebabkan turunnya konsumsi ransum dan lambatnya pertumbuhan (Asmara et al., 2007). Hal tersebut menyebabkan penurunan konsumsi, sehingga pertambahan bobot badan tertinggi terdapat pada perlakuan A dan menurun kembali seiring dengan bertambah pemberian jumlah eceng gondok fermentasi pada ransum $\mathrm{D}$, selain itu faktor yang mempengaruhi pertambahan bobot badan sapi Aceh jantan karena adanya kandungan logam pada eceng gondok, yang mempengaruhi pencernaan dan penyerapan mineral di dalam metabolisme tubuh ternak. Hal ini sesuai dengan pendapat Rumahlatuet al. (2012) yang menyatakan bahwa logam berat $\mathrm{Cd}$ (Kadmium) dapat menghambat pengambilan (uptake) nutrisi, menghambat aktivitas enzim, termasuk sistem antioksidan organisme hidup.

Pertumbuhan yang cepat terjadi pada periode lahir hingga usia penyapihan dan pubertas, namun setelah usia pubertas hingga usia dewasa pertumbuhannya menjadi lambat (Tomaszeweska, 1933 dalam Manurung, 2008). Hal ini sesuai dengan pendapat Bambang (2005) bahwa usia penyapihan hingga usia puberitas laju pertumbuhan masih bertahan pesat, namun dari usia setelah puberitas hingga dewasa laju pertumbuhan berangsur menurun dan akan terus menurun.

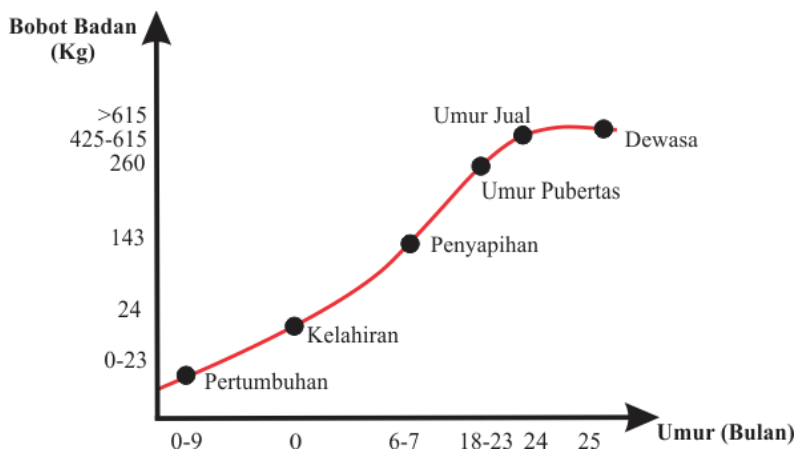

Gambar 2. Kurva Pertumbuhan Sapi (Sumber : Manurung 2008)

Menurut Lawrence dan Fowler (2002) kurva pertumbuhan ternak ruminansia terdiri dari tiga bagian, yaitu fase percepatan, diikuti fase linier atau pertumbuhan yang sangat cepat dengan waktu yang sangat pendek (dewasa kelamin) dan berakhir pada fase perlambatan yang berangsur-angsur menurun sampai ternak mencapai dewasa tubuh yang diilustrasikan dengan kurva 
berbentuk sigmoid.Potensi pertumbuhan ternak ditentukan oleh genetik yang dinyatakan dalam hubungan hormonal didalam tubuh, hal tersebut mengakibatkan adanya perbedaan dalam tingkat pertumbuhan dan bobot dewasa yang dicapai (Bamualim et al., 2002).

\section{Konsumsi Pakan}

Konsumsi pakan merupakan faktor yang penting dalam menentukan jumlah danefisiensi produktifitas ruminansia, dimana ukuran tubuh ternak sangat mempengaruhi konsumsi pakan (Elita, 2006). Ada beberapa faktor yang mempegaruhi konsumsi pakan pada sapi, yaitu : faktor ternak, keadaan pakan, $\mathrm{pH}$ cairan didalam rumen yang disebabkan oleh pengaruh fermentasi pakan, dan faktor luar seperti suhu dan kelembaban udara (Sarwono et al., 2001). Rataan Konsumsi ransum penelitian dapat dilihat pada Tabel 7.

Tabel 7. Konsumsi Ransum Sapi Aceh Jantan (kg/Hari/Ekor)

\begin{tabular}{|c|c|c|c|c|c|c|}
\hline \multirow{2}{*}{ Periode } & \multicolumn{4}{|c|}{ Perlakuan } & \multirow{2}{*}{ Total } & \multirow{2}{*}{ Rerata } \\
\hline & $\mathrm{A}$ & B & $\mathrm{C}$ & $\mathrm{D}$ & & \\
\hline I & 5,40 & 5,24 & 5,21 & 5,06 & 20,91 & 5,23 \\
\hline II & 4,82 & 5,29 & 5,04 & 4,95 & 20,10 & 5,02 \\
\hline III & 5,17 & 4,95 & 5,19 & 5,04 & 20,35 & 5,09 \\
\hline IV & 5,12 & 5,10 & 4,98 & 5,19 & 20,40 & 5,10 \\
\hline Total & 20,51 & 20,58 & 20,43 & 20,24 & 81,76 & \\
\hline Rerata & $\begin{array}{c}5,13 \\
\pm 0,120\end{array}$ & $\begin{array}{c}5,14 \\
\pm 0,075\end{array}$ & $\begin{array}{c}5,11 \\
\pm 0,056\end{array}$ & $\begin{array}{c}5,06 \\
\pm 0,049\end{array}$ & & \\
\hline
\end{tabular}

Keterangan: Nilai rerata dalam kolom yang sama secara statistik tidak berbeda nyata $(\mathrm{p}>0,05)$

Analisis ragam memperlihatkan bahwa penambahan berbagai level eceng godok fermentasimenunjukkan hasil yang tidak berbeda nyata $(\mathrm{P}>0.05)$ terhadap konsumsi pakan Sapi Aceh jantan. Rata-rata konsumsi ransumcenderung lebih tinggi pada perlakuan $\mathrm{B}=5,14 \pm 0,075 \mathrm{~kg} / \mathrm{ekor} / \mathrm{minggu} \mathrm{A}=5,13 \pm 0,120$ $\mathrm{kg} /$ ekor/minggu, $\quad \mathrm{C}=5,11 \pm 0,056 \mathrm{~kg} /$ ekor/minggu, $\mathrm{D}=5,06 \pm 0,049$ $\mathrm{kg} / \mathrm{ekor} /$ minggu.

Terjadi penurunan konsumsi ransum pada perlakuanD, disebabkan adanya perbedaan imbangan kadar energi dalam ransum. Jumlah kandungan eceng gondok fermentasi dalam perlakuan D mencapai 30\%, menyebabkan rendahnya palatabilitas sehingga konsumsi pakan menjadi rendah maka terjadinya penurunan energi metabolisme. Hal ini sesuai dengan pendapat Mangisah et al. (2009) yang menyatakan bahwa penggunaan eceng gondok fermentasi yang semakin tinggi dalam ransum menyebabkan kecernaan nutrient ransum menurun dan ketersediaan energi metabolis menurun sehingga berakibat pada rendahnya pertambahan bobot badan.

Menurut Tillman et al. (1991) kemampuan konsumsi pakan setiap sapi perharinya dalam bentuk bahan kering sebanyak $3 \%$ dari berat badannya. Rerata konsumsi bahan kering sapi yang diamati selama masa penelitian adalah 8,42 $\mathrm{kg} / \mathrm{ekor} / \mathrm{hari}$ atau sebesar $2,74 \%$ dari rerata bobot badan sapi potong. Dari data tersebut diketahui bahwa konsumsi bahan kering sapi selama penelitian hampir mencukupi dari kebutuhan. Hal ini juga sesuai dengan pendapat Azwani (2005), bahwa tidak semua ternak yang mengkonsumsi ransum yang lebih banyak, pertumbuhannnya lebih tinggi dibandingkan dengan ternak yang mengkonsusmsi lebih sedikit. Tapi apabila dalam ransum terjadi keseimbangan protein dan energi 
yang baik maka pertambahan berat badannya akan meningkat, selain faktor genetik, palatabilitas dan lingkungan juga mempengaruhi pertambahan berat badan tersebut.

Parakkasi (1999) menyatakan bahwa salah satu faktor yang menjadi penentu tingkat konsumsi adalah keseimbangan zat pakan dan palatabilitas.Palatabilitas pakan tergantung pada bau, rasa, tekstur, dan temperatur pakan yang diberikan.Pakan yang berkualitas baik, tingkat konsumsinya juga relatif lebih tinggi dibandingkan dengan pakan yang berkualitas lebih rendah, ternak yang mempunyai sifat dan kapasitas konsumsi yang lebih tinggi, produksinya juga bisa rendah (Kartadisastra, 1997).

Tinggi rendahnya konsumsi pakan pada ternak ruminansia sangat dipengaruhi oleh faktor eksternal yaitu: tempat tinggal (kandang), palatabilitas, komposisi nutrisi, bentuk pakan dan faktor internal yaitu: selera, status fisiologi, bobot tubuh dan produksi ternak itu sendiri (Kusumaningrum, 2009).

\section{Konversi Pakan}

Konversi merupakan metode untuk mengetahui berapa jumlah pakan yangdikonsumsi untuk menghasilkan $1 \mathrm{~kg}$ berat badan.Rataan konversi dapat dilihat pada Tabel 8 berikut.

Tabel 8. Konversi Pakan Sapi Aceh Jantan (kg/Hari/Ekor dalam bentuk bahan kering)

\begin{tabular}{|c|c|c|c|c|c|c|}
\hline \multirow{2}{*}{ Periode } & \multicolumn{4}{|c|}{ Perlakuan } & \multirow{2}{*}{ Total } & \multirow{2}{*}{ Rerata } \\
\hline & A & B & $\mathrm{C}$ & D & & \\
\hline I & 11,34 & 13,75 & 15,63 & 26,59 & 67,31 & 16,83 \\
\hline II & 10,09 & 13,24 & 12,99 & 14,45 & 50,77 & 12,69 \\
\hline III & 10,91 & 13,23 & 18,09 & 13,00 & 55,22 & 13,81 \\
\hline IV & 13,62 & 11,96 & 11,91 & 34,89 & 72,37 & 18,09 \\
\hline Total & 45,96 & 52,17 & 58,62 & 88,93 & 245,68 & \\
\hline Rerata & $\begin{array}{c}11,49 \\
\pm 0,755 \\
\end{array}$ & $\begin{array}{c}13,04 \\
\pm 0,382 \\
\end{array}$ & $\begin{array}{c}14,66 \\
\pm 1,387 \\
\end{array}$ & $\begin{array}{c}22,23 \\
\pm 5,205\end{array}$ & & \\
\hline
\end{tabular}

Keterangan: Nilai rerata dalam kolom yang sama secara statistik tidak berbeda nyata $(\mathrm{p}>0,05)$

Berdasarkan konversi pakan sapi Aceh jantan pada Tabel 6 diatas menunjukkan bahwa hasil uji antara perlakuan tidak berbeda nyata ( $\mathrm{P}>0,05)$. Rataan konversi pakan terjelek terdapat pada perlakuan D $(22,23 \pm 5,205 \mathrm{~kg})$ diikuti perlakuan C $(14,66 \pm 1,387 \mathrm{~kg}), \mathrm{B}(13,04 \pm 0,382 \mathrm{~kg})$ dan $\mathrm{A}(11,49 \pm 0,755$ $\mathrm{kg}$ ). Subtitusi eceng gondok fermentasi yang dapat diberikan pada sapi Aceh tidak lebih dari $20 \%$, karena pada pemberian eceng gondok fermentasi dalam pakan mengakibatkan tingginya angka konversi pakan yang menunjukkan terjadinya penurunan pertambahan berat badan pada sapi Aceh.

Konversi ransum diukur dari jumlah bahan kering yang dikonsumsi dibagi dengan pertambahan bobot badan persatuan waktunya.Konversi ransum khususnya pada ternak ruminansia dipengaruhi oleh kualitas pakan, pertambahan bobot badan dan nilai kecernaan. Dengan memberikan kualitas pakan yang baik ternak akan tumbuh lebih cepat dan lebih baik konversi ransumnya (Martawidjaja et al.,2001). Pada pemberian pakan perlakuan subtitusi eceng gondok fermentasi pada sapi Aceh jantan diperoleh nilai rata-rata konversi pakan sebesar 15,36 
Dengan demikian dapat disimpulkan bahwa untuk menghasilkan $1 \mathrm{~kg}$ bobot badan membutuhkan pakan perlakuan $15,36 \mathrm{~kg}$ bahan kering.

Nilai konversi ransum yang baik terdapat pada perlakuan A, Perlakuan A memiliki konsumsi ransum yang tinggi yaitu konsumsi bahan kering $5,13 \mathrm{~kg}$ dapat meningkatkan pertambahan berat badan 0,46 kg/ekor/hari. Angka konversi ransum yang baik dimana konsumsi ransum yang rendah dapat meningkatkan pertambahan berat badan yang tinggi. Seperti yang diungkapkan oleh Maynard dan Lossly (1979) bahwa semakin tinggi nilai gizi dalam ransum, maka konversi ransum akan semakin rendah sehingga menunjukkan efesiensi penggunaan ransum menjadi lebih baik. Jumlah zat gizi yang dibutuhkan dan kemampuan mengkonsumsi ransum bagi ternak ruminansia akan sangat tergantung pada bobot badan ternak bersangkutan ( Siregar, 1994).

Berdasarkan beberapa penelitian sebelumnya mengenai penambahan eceng gondok dalam ransum ayampetelur $10 \%$ yang dilaporkan tidak merugikan baik terhadap produksi telur atau dalam kualitas telurnya yang menunjukkan adanya pengaruh terhadap kuning telur mungkin disebabkan tingginya provitamin A dalam eceng gondok, sedangkan penambahan $15 \%$ dan $30 \%$ eceng gondok ke dalam ransum itik tidak menunjukkan perbedaan nyata dalam konsumi ransum ataupun terhadap pertambahan bobot badan itik (Marlina dan Askar, 2001). Pada penelitian lain, penggunaan eceng gondok sebagai pakan ternak diketahui bahwa pemberian eceng gondok sampai $15 \%$ pada ayam pedaging sampai umur 6 minggu tidak berpengaruh terhadap konsumsi, bobot hidup, konversi pakan (Mahmilia, 2005), sedangkan penggunaan eceng gondok segar sebagai pakan sapi pada fase pertumbuhan penggunaannya tidak lebih dari $30 \%$ dari bahan kering ke dalam pakan (Tham, 2012).

\section{KESIMPULAN DAN SARAN}

Pemberian pakan eceng gondok yang di fermentasi dengan aspergillus niger sebagai subtitusi rumput gajah dan rumput lapangan berpengaruh nyata terhadap pertambahan berat badan, namun konsumsi pakan dan konversi pakan tidak berpengaruh nyata terhadap sapi Aceh jantan. Menurut hasil uji duncan pada parameter pertambahan berat badan menunjukakan perbedaan yang nyata $(\mathrm{P}<0,05)$ antara pakan perlakuan $\mathrm{D}$ dengan pakan peerlakuan $\mathrm{A}, \mathrm{B}$ dan $\mathrm{C}$.

Eceng gondok fermentasi pada penelitian ini mempunyai tingkat palatabilitas yang rendah pada pemberian pakan D (30\%) sehingga terjadi penurunan tingkat konsumsi pakan dan terjadi penurunan pertambahan berat badan. Semakin tinggi penambahan persentase subtitusi eceng gondok fermentasi semakin tinggi nilai konversi pakan. Subtitusi eceng gondok fermentasi pada sapi Aceh dapat diberikan tidak lebih dari $20 \%$ dalam pakan perlakuan, penggunaan $30 \%$ eceng gondok dalam pakan dapat menurunkan pertambahan berat badan, konsumsi pakan dan konversi pakan menjadi tinggi.

Diharapkan agar dilakukan penelitian lebih lanjut dengan melakukan fermentasi menggunakan probiotik yang lain supaya pemberian eceng gondok fermentasi bisa di berikan lebih banyak untuk mendapatkan produksi yang tinggi dan dapat memenuhi kebutuhan nutrisi untuk ternak sehinggabisa memacu pertumbuhan yang optimal pada sapi Aceh sehingga lebih banyak data serta referensi untuk dijadikan sebagai acuan pada penelitian - penelitian berikutnya. 


\section{DAFTAR PUSTAKA}

Asmara, I.Y., D. Garnida, dan W. Tanwiriah.2007. Peampilan Broiler yang Diberi Ransum Mengandung Tepung Daun Ubi Jalar (Ipomea batatas) Terhadap Karakteristik Karkas.Jurnal. Indonesia. Tropical.Animal.Agricultur.32[2] Juni. Fakultas Peternakan, Universitas Padjadjaran. Bandung.

Azwani, D. 2005. Pengaruh Pemberian Silase Rumput Gajah yang Difermentasi dengan Urea dan Molases terhadap Pertambahan Bobot Badan Kambing Jantan Lokal. Skripsi Fakultas Pertanian Universitas Syiah Kuala, Banda Aceh.

Bambang S. Y. 2005. Sapi Potong. Penebar Swadaya. Jakarta.

Bamualim, A. dan R. B. Wirdahayati. 2002. Nutrition and management strategies to improve Bali cattle productivity in Nusa Tenggara. Proc. of an ACIAR Workshop on Strategies to Improve Bali Cattle in Eastern Indonesia. Skripsi Jurusan Nutrisi dan Makanan Ternak Fakultas Peternakan Universitas Brawijaya. Malang.

Elita, A. S. 2006. Studi perbandingan penampilan umum dan kecernaan pakan pada kambing dan domba lokal. Skripsi. Fakultas Peternakan, Institut Pertanian Bogor, Bogor.

Fitrihidajati, H., Ratnasari, E.,Isnawati., dan Soeparno, G. 2015. Kualitas Hasil Fermentasi Pada Pembuatan Pakan Ternak Ruminansia Berbahan Baku Eceng Gondok (Eichornia crassipes).Journal of Biology \& Biology Education. Vol 7 (1).

Kartadisastra, H.R., 1997. Pakan Ternak Ruminansia. Kanisius. Yogyakarta.

Kusumaningrum, B. I. 2009. Kajian Kualitas Ransum Kambing Peranakan Ettawa di Balai Pembibitan dan Budidaya Ternak Ruminansi Kendal.Fakultas Peternakan Universitas diponegoro, Semarang.

Lawrence, W.G. and V.R, Fowler. 2002. Growth of Farm Animals. 2 Ed. CABI Publishing. London.

Lubis, D. A. 1992 .Ilmu Makanan Ternak. PT Pembangunan. Jakarta.

Mahmilia, F. 2005. Perubahan Nilai Gizi Tepung Eceng Gondok Fermentasi Dan Pemanfaatannya Sebagai Ransum Ayam Pedaging. Jurnal. Loka Penelitian Kambing Potong. Sumatera Utara. Vol 10 (2).

Mangisah, I., H. Nasoetion, M and Sumarsih. S. 2003. Evaluasi Nilai Nutrisi Eceng Gondok Terfementasi Aspergillus niger Sebagai Alternatif Pakan. pusat penelitian dan pengembangan teknologi universitas diponegoro, Semarang.

Mangisah, I., B. Sukamto dan M. H. Nasution. 2009. Implementasi Daun Eceng Gondok Fermentasi Dalam Ransum Itik.Jurnal. Fakultas Peternakan, Universitas Diponegoro. Semarang.

Manurung L. 2008. Analisi ekonomi uji ransum berbasis pelepah daun sawit, lumpur sawit dan jerami padi fermentasi dengan phanerochate Chysosporium Pada Sapi Peranakan Ongole.Departemen Peternakan Fakultas Pertanian Universitas Sumatra Utara. Medan.

Marlina, N. dan S. Askar.2001. Nilai Gizi Eceng Gondok dan PemanfaatanSebagai Pakan Ternak Non Ruminansia.Jurnal. Balai Penelitian Ternak.Bogor.Temu Teknis Fungsional Non Peneliti.Hlm. 58-62. 
Martawidjaja, M., Kuswandi dan B. Setiadi. 2001. Pengaruh Tingkat Protein Ransum Terhadap Penampilan Kambing Persilangan Boer dan Kacang. Proc. Seminar Nasional Teknologi Peternakan dan Veteriner. Puslitbang Pertanian. Bogor.

Maynard, L. A. Loosly, J. K. Hintz, H. F. and Warner, R. G., 1979, Animal Nutrition. Mc Graw-Hill Publishing Press, Bombay, New Delhi.

Parakkasi, 1999. Ilmu Nutrisi dan Makanan Ternak Ruminan, UI Press. Jakarta.

Rumahlatu, D. A. D. Corebima, M. Amin, dan F. Rachman. 2012. Kadmium dan Efeknya Terhadap Ekspresi Protein Metallothionein Pada Deadema setosum (Echinoidea; Echinodermata).Jurnal. Progam Studi Pendidikan Biologi, FKIP Universitas. Pattimura, Ambon.

Saleh, E. J. Rifaidan E. Sari.2005. Pengaruh Pemberian Tepung Eceng Gondok (Eichornia grassipes) dan Paku Air (Azolla pinnata) Fermentasi Terhadap Performans Ayam Broiler.Jurnal Agribisnis Peternakan, Vol. 1 (3).

Siregar, A. P. 1994. Tehnik Beternak Ayam Pedaging. Merdie Group. Jakarta.

Tillman, A.D., H. Hartadi, S. Reksohadiprodjo, S. Prawirokusumo dan S. Lebdosoekojo. 1991. Ilmu Makanan Ternak Dasar. Gadjah Mada University Press, Yogyakarta.

Tham, H. T. 2012. Water Hyacinth - Biomass Production, Ensilability and Feeding Value to Growin Cattle. Master of Thesis. Swedish University of Agriculture Sciences. Swedia. 